\title{
Omission of Lime Reduces Mouse-ear Symptoms in Container-grown Pecan Trees
}

\author{
William D. Goff and Gary J. Keever \\ Department of Horticulture and Alabama Agricultural Experiment Station \\ Auburn University, AL 36849
}

Additional index words. Carya illinoensis, little-leaf, manganese, container culture, fertilization, soil amendments, $\mathrm{pH}$

\begin{abstract}
Container-grown pecan [Carya illinoensis (Wangenh.) C. Koch] trees with "mouse-ear" symptoms, characterized by small, rounded, cupped, and slightly wrinkled leaflets, were repotted into two types of media amended with three rates of dolomitic limestone $\left(0,5.4\right.$, or $\left.10.7 \mathrm{~kg} \cdot \mathrm{m}^{-3}\right)$. In both media [4 milled pine bark: 1 sand; 1 soil : 1 peat : 1 perlite (by volume)], mouse-ear symptoms in the season following repotting were dramatically reduced at the lower lime application rates. Medium Fe, $\mathrm{Ca}, \mathrm{Cu}$, and $\mathrm{Mn}$ and foliar $\mathrm{Ca}, \mathrm{Mg}, \mathrm{Mn}, \mathrm{Zn}$, and $\mathrm{B}$ were affected by lime rate 10 months after repotting in one or both media. Medium $\mathrm{pH}$ increased quadratically as lime rate increased. Greatest plant recovery occurred when no lime was added, resulting in a pH of 3.9 in the bark-sand medium and 4.2 in the soil-peat-perlite medium.
\end{abstract}

"Mouse-ear" describes abnormal growth in pecan trees characterized by small, rounded, cupped, and slightly wrinkled leaves (Gammon and Sharpe, 1956). In orchards, it has been associated with soil $\mathrm{pH}$ of 6.5 to 8.0 and was thought to be caused by $\mathrm{Mn}$ deficiency (Gammon and Sharpe, 1956). Later research (Gallaher and Jones, 1976; Grauke et al., 1983; Worley, 1979) found similar symptoms in nonmanganese-deficient trees, suggesting a more complex or different problem. Gallaher and Jones (1976) suggested $\mathrm{Ca}$ deficiency, but their research showed higher $\mathrm{Ca}, \mathrm{Mn}, \mathrm{Fe}, \mathrm{Cu}, \mathrm{Zn}$, and $\mathrm{Mo}$ and less $\mathrm{Mg}$ in leaf and stem tissue from affected trees. Worley (1979) reported elemental concentrations of normal and mouseeared leaflets differed among cultivars, with inconsistencies and reversals in element concentrations of affected leaflets occurring for particular cultivars and locations. Grauke et al. (1983) observed higher N, P, Ca, S, and $\mathrm{Mn}$ and lower $\mathrm{Fe}$ in mouse-eared leaves from container-grown trees. They suggested that high $\mathrm{N}$ levels were lowering the $\mathrm{N}: \mathrm{S}$ ratio and that correspondingly high levels of $\mathrm{S}$ may be needed for normal growth.

Two container pecan nurseries in Alabama

Received for publication 23 Mar. 1990. AAES Journal Series no. 11-902497P. Appreciation is expressed to Nguyen Hue and John McGuire for assistance in statistical analysis and interpretation, and to Margaret Horton for use of her trees. The cost of publishing this paper was defrayed in part by the payment of page charges. Under postal regulations, this paper therefore must be hereby marked advertisement solely to indicate this fact.

The nursery trees selected for this experiment were growing in 11.4-liter containers in a 3 milled pine bark : 1 sand medium omitted. $(\mathrm{v} / \mathrm{v})$ amended with $\left(\mathrm{kg} \cdot \mathrm{m}^{-3}\right) 8.9$ dolomitic limestone, 3.6 Sierrablen Nursery Mix 18N3. 0P-8.3K-1Fe (Grace-Sierra), Milpitas, Calif.), 0.65 gypsum, and 0.9 Micromax micronutrients (Grace-Sierra). Supplemental applications of $14.2 \mathrm{~g}$ of Sta-Green Nursery Special (12N-2.6P-5.0K) (Sta-Green Plant Food Co., Sylacauga, Ala.) per container had been applied monthly from Mar. to Oct. 1984 and from Mar. to June 1985. Before beginning the treatments in July 1985, leaf samples were taken from 25 randomly selected trees exhibiting mouse-ear symptoms and from 25 healthy trees. These leaves were analyzed for $\mathrm{B}, \mathrm{Ca}, \mathrm{Cu}, \mathrm{Fe}, \mathrm{Mg}, \mathrm{Mn}, \mathrm{P}$, and $\mathrm{Zn}$.

In July 1985, 126 trees exhibiting severe mouse-ear symptoms were selected and subjected to a factorial combination of two repotting media [4 milled pine bark : 1 sand or 1 soil : 1 peat : 1 perlite (by volume)] and three rates of incorporated dolomitic limestone $(20 \% \mathrm{Ca}, 8.0 \% \mathrm{Mg})$ at $0,5.4$, or 10.7 $\mathrm{kg} \cdot \mathrm{m}^{-3}$. Selected trees of uniform height were assigned at random to the treatment media and were repotted on 3 July 1985 . All combinations were amended with $\left(\mathrm{kg} \cdot \mathrm{m}^{-3}\right) 5.9$ Osmocote $18 \mathrm{~N}-2.6 \mathrm{P}-10.0 \mathrm{~K}, 1.2$ gypsum, 1.2 superphosphate $(0 \mathrm{~N}-8.6 \mathrm{P}-0 \mathrm{~K})$, and 0.9 Micromax. Trees grown in nonlimed media received monthly applications of $18 \mathrm{~g}$ of gypsum plus $5.7 \mathrm{~g}$ Epsom salt/pot to supply $\mathrm{Ca}$ and $\mathrm{Mg}$. Treatments were completely randomized, with seven three-tree replicates per treatment combination.

Media were analyzed on 12 July 1985, 10 days after repotting, for $\mathrm{B}, \mathrm{Ca}, \mathrm{Cu}, \mathrm{Fe}, \mathrm{K}$, $\mathrm{Mg}, \mathrm{Mn}, \mathrm{P}$, and $\mathrm{Zn}$ and for $\mathrm{pH}$ and soluble salts using the saturated media extraction

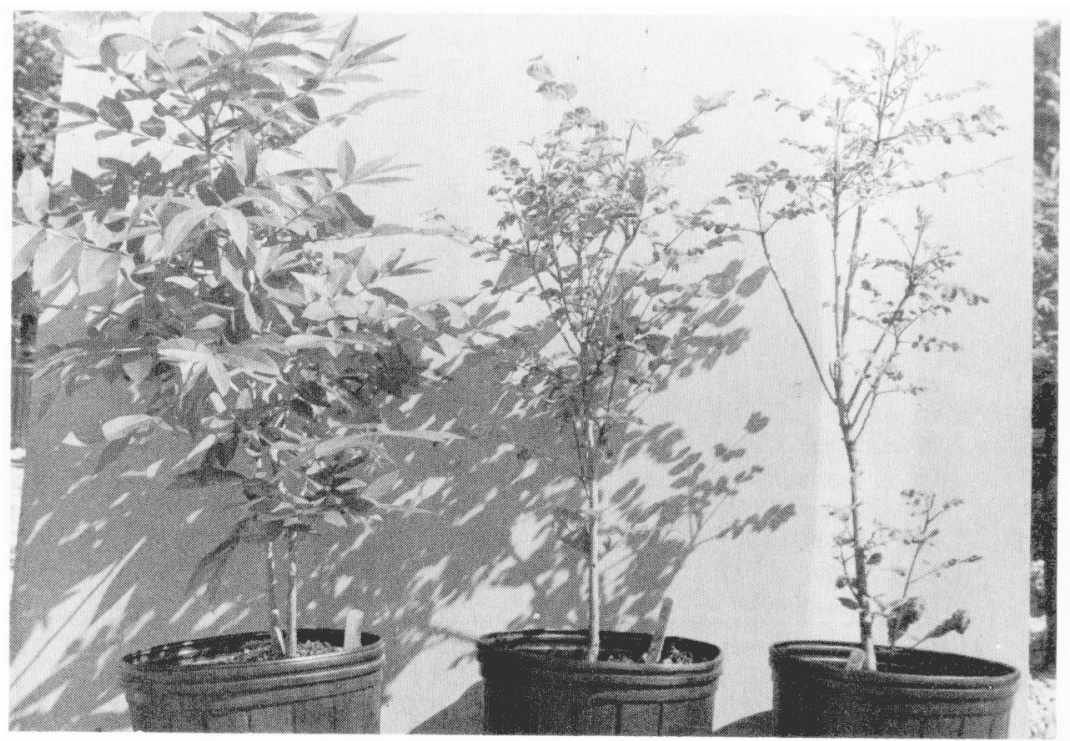

Fig. 1. Mouse-ear symptoms on container-grown pecan trees on 25 Apr. 1986, 10 months after repotting severely affected trees into media into which dolomitic lime at 0 (left), 5.4 , or $10.7 \mathrm{~kg} \cdot \mathrm{m}^{3}$ had been incorporated. Note almost complete recovery from symptoms in plants where lime was 
Table 1. Effect of lime in repotting media on recovery of container-grown pecan trees from mouseear symptoms (1986).

\begin{tabular}{|c|c|c|c|c|c|}
\hline \multirow[b]{2}{*}{ Medium } & \multirow{2}{*}{$\begin{array}{c}\text { Lime } \\
\text { applied } \\
\left(\mathrm{kg} \cdot \mathrm{m}^{-3}\right)\end{array}$} & \multicolumn{2}{|c|}{ Severity rating ${ }^{2}$} & $\begin{array}{l}\text { Leaf } \\
\text { lengthy } \\
\text { (cm) }\end{array}$ & $\begin{array}{c}\text { Plant } \\
\text { ht } \\
\text { (cm) }\end{array}$ \\
\hline & & 25 Apr. & 24 Sept. & \multicolumn{2}{|c|}{$25 \mathrm{Apr}}$. \\
\hline \multirow[t]{3}{*}{ Bark--sand (BS) } & 0 & 4.9 & 4.3 & 30.3 & 94.3 \\
\hline & 5.4 & 2.9 & 4.1 & 17.0 & 88.5 \\
\hline & 10.7 & 2.4 & 3.3 & 15.0 & 86.5 \\
\hline \multirow[t]{3}{*}{ Soil-peat-perlite (SPP) } & 0 & 4.9 & 4.3 & 29.1 & 73.9 \\
\hline & 5.4 & 3.5 & 4.2 & 17.0 & 77.3 \\
\hline & 10.7 & 2.9 & 3.7 & 14.2 & 71.6 \\
\hline \multirow[t]{3}{*}{ Overall effect } & 0 & 4.9 & 4.3 & 29.8 & 84.1 \\
\hline & 5.4 & 3.2 & 4.1 & 1.7 .0 & 82.9 \\
\hline & 10.7 & 2.6 & 3.5 & 14.6 & 79.0 \\
\hline \multicolumn{6}{|l|}{ Significance } \\
\hline Medium & & ** & NS & NS & $* * *$ \\
\hline Lime & & $* * *$ & $* * *$ & $* * *$ & NS \\
\hline Medium $\times$ lime & & NS & NS & NS & NS \\
\hline \multicolumn{6}{|l|}{ Contrasts } \\
\hline Lime, linear & & $* * *$ & $* * *$ & $* * *$ & * \\
\hline Lime, quadratic & & $* * *$ & NS & $* * *$ & NS \\
\hline Limc, linear in BS & & $* * *$ & $* * *$ & $* * *$ & $*$ \\
\hline Lime, quadratic in BS & & $* * *$ & NS & $* * *$ & $*$ \\
\hline Lime, lincar in SPP & & $* * *$ & ** & *** & NS \\
\hline Lime, quadratic in SPP & & * & NS & $* * *$ & NS \\
\hline
\end{tabular}

${ }^{2}$ Scale of 1 to 5 , where 1 = severely mouse-eared and $5=$ normal; ratings made 25 Apr. 1986 were $\approx 10$ months after affected trees were repotted and those made 24 Sept. 1986 were $\approx 15$ months after repotting.

'Length of compound leaf in middle of current season's shoot.

NS,*,**,*** Not significant or significant at $P=0.05,0.01$, or 0.001 , respectively. method of Warnke and Krauskopf (1983). Foliar samples were taken from treated trees 10 months after repotting (May 1986). The samples consisted of a single compound leaf collected from the middle of current season's shoots on each plant and analyzed for $\mathrm{B}, \mathrm{Ca}$, $\mathrm{Cu}, \mathrm{Fe}, \mathrm{K}, \mathrm{Mg}, \mathrm{Mn}, \mathrm{P}$, and $\mathrm{Zn}$ using a dry ashing technique (Hue and Evans, 1986).

Foliage was rated for mouse-ear severity (1-5 scale, where $1=$ severely mouse-eared and $5=$ healthy) on 25 Apr. 1986 and again on 24 Sept. 1986. Plant height and leaflet length were measured on 25 Apr. 1986.

Ten and 15 months after repotting, mouseear symptoms were dramatically reduced (Fig. 1, Table 1) as lime application decreased. Leaf length, another measure of symptom expression, followed a similar pattern, with short deformed leaves present on plants grown in the highest lime application and a quadratic increase in leaf length as lime application decreased (Table 1). Plant height also increased quadratically in the bark-sand medium as the amount of lime decreased, but was unaffected by lime in the soil-peat-perlite medium.

Pretreatment foliar elemental concentrations of $\mathrm{Ca}, \mathrm{Mg}, \mathrm{P}$, and $\mathrm{Cu}$ in trees exhibiting mouse-ear symptoms were higher $(P<$ 0.05 ) than in normal trees, while concentrations of $\mathrm{Mn}, \mathrm{K}, \mathrm{Zn}$, and $\mathrm{B}$ were lower in

Table 2. Foliar nutrient levels pretreatment and 10 months after repotting of pecan trees as affected by lime application.

\begin{tabular}{|c|c|c|c|c|c|c|c|c|c|c|}
\hline \multirow{3}{*}{$\begin{array}{l}\text { Condition } \\
\text { or } \\
\text { medium }\end{array}$} & \multirow{3}{*}{$\begin{array}{c}\text { Lime } \\
\text { applied } \\
\left(\mathrm{kg} \cdot \mathrm{m}^{-3}\right)\end{array}$} & \multicolumn{9}{|c|}{ Concn (dry-wt basis) of elements in foliage ${ }^{z}$} \\
\hline & & \multicolumn{4}{|c|}{ Percent } & \multicolumn{5}{|c|}{$\mu \mathrm{g} \cdot \mathrm{g}^{-1}$} \\
\hline & & $\mathrm{Ca}$ & $\mathrm{K}$ & $\mathrm{Mg}$ & $\mathrm{P}$ & B & $\mathrm{Cu}$ & $\mathrm{Fe}$ & $\mathrm{Mn}$ & $\mathrm{Zn}$ \\
\hline & \multicolumn{10}{|c|}{ Pretreatmenty } \\
\hline Mousc-ear & & $0.80 \mathrm{a}$ & $0.48 \mathrm{a}$ & $0.38 \mathrm{a}$ & $0.12 \mathrm{a}$ & $26.7 \mathrm{a}$ & $6.7 \mathrm{a}$ & $191 \mathrm{a}$ & $116 \mathbf{a}$ & $63 \mathrm{a}$ \\
\hline \multirow[t]{2}{*}{ Normal } & & $0.64 \mathrm{~b}$ & $0.56 \mathrm{~b}$ & $0.21 \mathrm{~b}$ & $0.09 \mathrm{~b}$ & $46.4 \mathrm{~b}$ & $5.6 \mathrm{~b}$ & $131 \mathrm{a}$ & $550 \mathrm{~b}$ & $81 \mathrm{~b}$ \\
\hline & \multicolumn{10}{|c|}{ Interactions } \\
\hline \multirow{3}{*}{ Bark-sand (BS) } & 0 & 0.64 & 0.85 & 0.24 & 0.22 & 18.2 & 5.6 & 90 & 421 & 139 \\
\hline & 5.3 & 1.39 & 0.83 & 0.69 & 0.23 & 30.6 & 5.0 & 179 & 290 & 177 \\
\hline & 10.7 & 1.21 & 0.96 & 0.75 & 0.30 & 34.4 & 2.5 & 164 & 116 & 128 \\
\hline \multirow[t]{7}{*}{ Soil-peat-perlite (SPP) } & 0 & 0.96 & 0.92 & 0.21 & 0.23 & 31.0 & 30.1 & 110 & 455 & 173 \\
\hline & 5.3 & 1.38 & 0.83 & 0.56 & 0.21 & 51.8 & 21.2 & 125 & 611 & 189 \\
\hline & 10.7 & 1.13 & 0.95 & 0.51 & 0.27 & 33.8 & 11.4 & 179 & 272 & 119 \\
\hline & \multicolumn{10}{|c|}{ Main effects } \\
\hline & 0 & 0.80 & 0.89 & 0.23 & 0.23 & 24.6 & 17.9 & 100 & 438 & 156 \\
\hline & 5.3 & 1.39 & 0.83 & 0.63 & 0.23 & 41.2 & 13.1 & 152 & 451 & 183 \\
\hline & 10.7 & 1.17 & 0.95 & 0.63 & 0.28 & 34.1 & 7.0 & 172 & 194 & 124 \\
\hline \multicolumn{11}{|l|}{ Significance } \\
\hline Media & & NS & NS & $* * *$ & NS & * & $* *$ & NS & $* * *$ & NS \\
\hline Lime & & $* * *$ & $*$ & $* * *$ & $* *$ & * & NS & $*$ & $* * *$ & $* *$ \\
\hline Media $\times$ lime & & $*$ & NS & $*$ & NS & NS & NS & NS & $* * *$ & NS \\
\hline \multicolumn{11}{|l|}{ Contrasts } \\
\hline Lime, lincar & & $* * *$ & NS & $* * *$ & $* *$ & NS & NS & $* *$ & $* * *$ & $*$ \\
\hline Limc, quadratic & & $* * *$ & $*$ & $* * *$ & NS & * & NS & NS & $* * *$ & ** \\
\hline Lime, lincar in BS & & $* * *$ & NS & $* * *$ & $* *$ & * & NS & $*$ & $* * *$ & NS \\
\hline Lime, quadratic in BS & & $* * *$ & NS & $* * *$ & NS & NS & NS & NS & NS & $*$ \\
\hline Lime, linear in SPP & & NS & NS & $* * *$ & NS & NS & * & * & $* * *$ & * \\
\hline Lime, quadratic in SPP & & $* *$ & NS & $* * *$ & NS & $* *$ & NS & NS & $* * *$ & $*$ \\
\hline
\end{tabular}

${ }^{7}$ Determined from whole compound leaves collected from the middle of current season's shoots in May 1986.

${ }^{\gamma}$ Pretreatment foliar samples taken 2 July 1986. Mean separation within elements by Fisher's F test, $P=0.05$. Not significant or significant at $P=0.05,0.01$, or 0.001 , respectively. 
Table 3. Nutrientlevels, pH, and soluble salts in repotting media on 12 July 1985, 10 days following repotting of pecan trees.

\begin{tabular}{|c|c|c|c|c|c|c|c|c|c|c|c|c|}
\hline \multirow[b]{2}{*}{ Medium } & \multirow{2}{*}{$\begin{array}{c}\text { Lime } \\
\text { applied } \\
\left(\mathrm{kg} \cdot \mathrm{m}^{-3}\right)\end{array}$} & \multirow[b]{2}{*}{$\mathrm{pH}$} & \multirow{2}{*}{$\begin{array}{l}\text { Conductivity } \\
(\mathrm{mmhos} / \mathrm{cm})\end{array}$} & \multicolumn{9}{|c|}{$\begin{array}{c}\text { Concn of elements in media } \\
\text { (mg } \cdot \text { liter }^{-1} \text { in solution) }\end{array}$} \\
\hline & & & & B & $\mathrm{Ca}$ & $\mathrm{Cu}$ & $\mathrm{Fe}$ & $\mathrm{K}$ & $\mathrm{Mg}$ & $\mathrm{Mn}$ & $\mathrm{P}$ & $\mathrm{Zn}$ \\
\hline \multicolumn{13}{|c|}{ Interactions } \\
\hline \multirow[t]{3}{*}{ Bark-sand (BS) } & 0 & 3.9 & 4.5 & 0.27 & 2.7 & 0.26 & 6.7 & 5.5 & 1.3 & 0.06 & 2.7 & 0.01 \\
\hline & 5.4 & 5.4 & 3.0 & 0.27 & 2.7 & 0.26 & 6.7 & 5.8 & 1.4 & 0.07 & 2.5 & 0.02 \\
\hline & 10.7 & 5.8 & 3.5 & 0.58 & 3.0 & 0.26 & 6.7 & 13.7 & 2.5 & 0.25 & 3.8 & 0.19 \\
\hline \multirow[t]{7}{*}{ Soil-peat-perlite (SPP) } & 0 & 4.2 & 3.3 & 0.58 & 3.0 & 0.26 & 6.7 & 13.1 & 2.5 & 0.25 & 3.9 & 0.18 \\
\hline & 5.4 & 5.6 & 2.4 & 0.67 & 7.6 & 0.27 & 6.9 & 15.4 & 3.0 & 0.35 & 4.1 & 0.20 \\
\hline & 10.7 & 5.8 & 2.1 & 0.58 & 42.4 & 0.32 & 8.0 & 14.7 & 4.3 & 0.69 & 6.0 & 0.47 \\
\hline & \multicolumn{12}{|c|}{ Main effects } \\
\hline & 0 & 4.0 & 3.9 & 0.43 & 2.8 & 0.26 & 6.7 & 9.3 & 1.9 & 0.16 & 3.3 & 0.10 \\
\hline & 5.4 & 5.5 & 2.7 & 0.47 & 5.1 & 0.27 & 6.8 & 10.6 & 2.2 & 0.21 & 3.3 & 0.11 \\
\hline & 10.7 & 5.8 & 2.8 & 0.58 & 22.7 & 0.29 & 7.3 & 14.2 & 3.4 & 0.47 & 4.9 & 0.33 \\
\hline \multicolumn{13}{|l|}{ Significance } \\
\hline Media & & $* * *$ & * & NS & ** & $* *$ & $* *$ & NS & NS & * & NS & NS \\
\hline Lime & & $* * *$ & NS & NS & ** & ** & $* *$ & NS & NS & NS & NS & NS \\
\hline Media $\times$ lime & & ** & NS & NS & *** & $* *$ & ** & NS & NS & NS & NS & NS \\
\hline \multicolumn{13}{|l|}{ Contrasts } \\
\hline Lime, linear & & **** & NS & NS & ** & ** & *** & NS & NS & NS & NS & NS \\
\hline Limc, quadratic & & $* * *$ & NS & NS & NS & NS & NS & NS & NS & NS & NS & NS \\
\hline Lime, linear in BS & & $* * *$ & NS & NS & NS & NS & NS & NS & NS & NS & NS & NS \\
\hline Lime, quadratic in BS & & $* * *$ & NS & NS & NS & NS & NS & NS & NS & NS & NS & NS \\
\hline Lime, linear in SPP & & $* * *$ & NS & NS & $* * *$ & $* * *$ & $* * *$ & NS & NS & * & NS & NS \\
\hline Lime, quadratic in SPP & & *** & NS & NS & $*$ & NS & * & NS & NS & NS & NS & NS \\
\hline
\end{tabular}

Not significant or significant at $P=0.05,0.01$, or 0.001 , respectively.

mouse-ear trees (Table 2). Leaf $\mathrm{Ca}, \mathrm{Mg}, \mathrm{Mn}$, $\mathrm{Zn}$, and B were clearly affected by lime application 10 months after plants were repotted in the treatment media. Foliar $\mathrm{Ca}$ was lowest without added lime, peaked at the intermediate level, then fell at the high level.

We do not know why foliar Ca decreased at the highest lime level, but observations of treated plants (Fig. 1) suggest two possible explanations. The disorder obviously severely affected plant function. Root function could have been disrupted to the point that the expected continued rise of foliar $\mathrm{Ca}$ was prevented because of poor root condition. Also, the foliar samples collected from normal leaves (Fig. 1, left) represent plant tissue considerably different from the tissue collected and analyzed from severely mouseeared foliage (Fig. 1, right). The relative proportion of leaf blade to stems and veins appears much greater in normal than in affected leaves, which have very little leaf blade development. This tissue dissimilarity could explain some of the otherwise confusing results we and others have obtained.

Foliar $\mathrm{Mg}$ followed a similar pattern as $\mathrm{Ca}$ in the soil-peat-perlite medium, but was higher at 10.7 than at $5.4 \mathrm{~kg} \cdot \mathrm{m}^{-3}$ in the barksand medium. Foliar Mn declined sharply in the bark-sand medium with an increase in lime application, but in soil-peat-perlite, $\mathrm{Mn}$ was highest with lime at $5.4 \mathrm{~kg} \cdot \mathrm{m}^{-3}$, then dropped sharply with lime at $10.7 \mathrm{~kg} \cdot \mathrm{m}^{-3}$. Foliar $\mathrm{Zn}$ followed the same pattern. Leaf B concentrations were positively related to lime rate in the bark-sand medium, but were curvilinearly related to lime rate in soil-peatperlite.

In both media, there was an increase in $\mathrm{pH}$ with an increase in lime application (Table 3). The plants that had the fewest mouseear symptoms were those grown without lime, with a $\mathrm{pH}$ of 3.9 in the bark-sand medium and 4.2 in soil-peat-perlite.
Nutrients significantly affected by lime rate in one or both media (Table 3 ) were Fe, Mn, $\mathrm{Cu}$, and $\mathrm{Ca} . \mathrm{Fe}, \mathrm{Mn}$, and $\mathrm{Cu}$ all increased linearly with lime application in soil-peatperlite but not in bark-sand. Calcium increased quadratically with the amount of lime applied to the soil-peat-perlite but also did not change in bark-sand.

Correlations of mouse-ear ratings with media and foliar elemental levels were computed. Magnesium level and $\mathrm{pH}$ of media solution 10 months after repotting were significantly $(P \leq 0.05)$ correlated with mouseear incidence. Foliar concentrations of $\mathrm{Mg}$, $\mathrm{Mn}, \mathrm{Zn}$, and Fe were also significantly correlated with mouse-ear incidence.

Regression analyses for leaf and media elemental levels with mouse-ear rating were conducted, and standardized b (stb) values (Steele and Torrie, 1980) were used to indicate relative importance of each variable. In media, $\mathrm{pH}$ was more important $(\mathrm{stb}=$ $0.56)$ than $\mathrm{Mg}(\mathrm{stb}=0.44)$. Leaf $\mathrm{Mg}$ was the most important element $(\mathrm{stb}=0.55)$ and $\mathrm{Fe}$ was second $(\mathrm{stb}=0.37)$, while $\mathrm{Zn}$ and $\mathrm{Mn}$ had relatively little influence on mouseear symptoms (stb $=0.11$ for each).

Results of this study and review of earlier work suggest that mouse-ear is a complex problem resulting from nutrient imbalance and that no single cause can explain all cases of symptom occurrence. Media $\mathrm{pH}$, however, clearly influenced mouse-ear symptoms. A consistent observation from reviewed work, as well as the present study, is that $\mathrm{Ca}$ concentration of affected leaves is higher than or equal to the $\mathrm{Ca}$ concentration of normal leaves. This is in agreement with our observation that using little or no lime can correct the problem. Our work also agrees with that of Gammon and Sharpe (1956) in that low $\mathrm{Mn}$, perhaps lime-induced (Sanchez and Kamprath, 1959), may contribute to the occurrence of mouse-ear symptoms in some in- stances. We observed no mouse-ear symptoms and good growth of several hundred container-grown pecan trees in a pine bark medium of similar composition to that which resulted in severe symptoms. The apparent major difference in the two media was that the lime rate in the medium producing plants with symptoms was high $\left(8.9 \mathrm{~kg} \cdot \mathrm{m}^{-3}\right)$, while it was low $\left(3.0 \mathrm{~kg} \cdot \mathrm{m}^{-3}\right)$ in the medium producing plants with no symptoms. This observation suggests that nursery workers may be able to avoid the mouse-ear problem by using little or no lime. Omitting lime in our experiment worked well as a corrective treatment on plants already exhibiting symptoms, but some lime may be needed for optimum performance of normal trees. We added supplemental $\mathrm{Ca}$ and $\mathrm{Mg}$ to the $0 \mathrm{~kg}$ lime $/ \mathrm{m}^{3}$ treatment, which also may be required if further experimentation shows that very low amounts of lime are necessary to eliminate this disorder.

\section{Literature Cited}

Gallaher, R.N. and J.B. Jones, Jr. 1976. Total extractable, and oxalate calcium and other elements in normal and mouse-ear pecan tree tissue. J. Amer. Soc. Hort. Sci. 101:692-696.

Gammon, N., Jr., and R.H. Sharpe. 1956. Mouseear-A manganese deficiency of pecans. Proc. Amer. Soc. Hort. Sci. 68:195-200.

Grauke, L.J., H.J. Morris, and J.G. Kowalczuk. 1983. "Mouse-ear": A symptom of nutrient imbalance. Proc. Southeastern Pecan Growers Assn. 76:141-147.

Hue, N.V. and C.E. Evans. 1986. Procedures used for soil and plant analysis by the Auburn Univ. soil testing laboratory. Auburn Univ. Dept. of Agron. and Soils Series 106.

Sanchez, C. and E.J. Kamprath. 1959. The effect of liming and organic matter content on the availability of native and applied manganese. Soil Sci. Soc. Amer. Proc. 23:302-306.

Steele, R.G.D. and J.H. Torrie. 1980. Principles 
and procedures of statistics. McGraw-Hill, New York.

Warnke, D.D. and Dean M. Krauskopf. 1983.
Greenhouse growth media: Testing and nutrition guidelines. Michigan State Univ. Ext. Bul. E-1736.
Worley, R.E. 1979. Pecan cultivars differ in leaf elemental concentration of normal and mouseear leaf tissue. HortScience 14:51-52. 